\title{
TERAPI PARENT CHILD INTERACTION TERAPHY (PCIT) UNTUK MENGURANGI PERILAKU KEKERASAN ORANGTUA TERHADAP ANAK
}

\author{
SRI WURYANTI \\ Widyaiswara Ahli Madya Pusdiklat Kesos Kemensos RI \\ Email : sri.wuryanti.sosial@gmail.com
}

Tujuan penelitian adalah untuk mengatasi kasus perilaku kekerasan ayah (A) terhadap anak (B). Penelitian menggunakan pendekatan kualitatif dengan disain penelitian tindakan (action research). Mengacu pada pendapat Robert Emerson yang dikutip oleh Grinnel (1997:107), penelitian kualitatif ditujukan untuk memahami bagaimana orang-orang hidup, berbicara dan bertingkah laku dan mencoba memahami apa yang menarik ataupun apa masalah-masalah mereka, dan yang paling penting adalah bagaimana memahami makna dari perilaku dan ucapan-ucapan mereka. Disain penelitian tindakan sebagai upaya mengujicobakan ide-ide ke dalam praktik untuk memperbaiki atau mengubah sesuatu agar memperoleh dampak nyata dari situasi (Kemmis, 1983). Pengumpulan data diperoleh melalui wawancara mendalam, observasi partisipatif dan studi dokumentasi. Sumber data terdiri dari sumber data primer, yaitu ayah (A) dan anak (B), sumber data sekunder yaitu ibu (tiri), kakak, serta adik kandung seayah. Sumber data tambahan berasal dari dokumen-dokumen yang berhubungan dengan sumber data primer. Pengujian validitas dan reliabilitas menggunakan uji kredibilitas dengan teknik perpanjangan keikutsertaan, ketekunan pengamatan, trianggulasi sumber, trianggulasi pengumpulan data, triangulasi waktu, pemeriksaan sejawat melalui diskusi, analisis kasus negatif, kecukupan referensi, pengecekan anggota, uraian rinci, dan auditing. Kesimpulan hasil penelitian menunjukan bahwa terapi PCIT melalui dua fase Child Directed-Intarction (CDI) dan Parent Directed-Interaction (PDI), efektif dapat memperbaiki hubungan orangtua dan anak menjadi penuh kehangatan serta orangtua mampu memberikan pola pengasuhan terhadap anak tanpa melakukan kekerasan baik secara fisik maupun psikhis. Implementasi teoritis bahwa terapi PCIT ini memberikan konstribusi menguatkan teori gaya pengasuhan autoritatif (autoritative parenting style) pengasuhan yang penuh dengan kehangatan dan menambah bukti empiris terhadap asumsi yang ada pada teori tersebut.

Kata kunci : terapi PCIT,mengurangi perilaku kekerasan orangtua terhadap anak

\section{PENDAHULUAN}

Kasus kekerasan pada anak semakin meningkat, korbanya, bukan hanya dari kalangan dewasa namun sekarang sudah merambah ke remaja, anak-anak bahkan balita. Fenomena kekerasan fisik dan psikis semakin sering terjadi dan semakin menglobal hampir di berbagai negara. Kasus kekerasan anak terus meningkat dari waktu kewaktu. Dan yang lebih tragis pelakunya adalah kebanyakan dari lingkungan keluarga yang terdekat, lingkungan sekitar anak itu berada, antar lain di dalam rumahnya sendiri, Sekolah, Lembaga Pendidikan, dan lingkungan sosial anak sebagaimana dikatakan (Noviana, 2015).

Dalam masa perkembangan anak dijamin dan dilindungi hak-haknya agar dapat hidup, tumbuh, berkembang, dan berpartisipasi secara optimal sesuai dengan harkat dan martabat kemanusiaan, serta mendapat perlindungan dari kekerasan dan deskriimasi. Kekerasan yang dimaksud adalah setiap perbuatan terhadap anak yang berakibat timbulnya kesengsaraan atau penderitaan secara fisik, seksual, dan atau penelantaran, termasuk ancaman untuk melakukan perbuatan, pemaksaan, atau perampasan kemerdekaan sebagaimana di atur oleh (UU RI, 2014)

Sebagai informan pendukung, yaitu orangtua/ibu tiri, kakak kandung, orang terdekat yang dipercaya responden dan guru wali kelasnya. Kasus kekerasa yang terjadi yaitu anak lakilaki berusia 11 tahun adalah anak dari hasil perselingkuhan ayahnya yang berinisial (A) dengan melakukan kekerasan kepada anaknya yang bernama inisial B.berusia 11 tahun. Kekerasan yang dilakukannya berupan kekerasan fisik maupun psikis berupa sabetan/pemukulan dengan menggunakan ikat pinggang, dan kecaman/makian. Akibatnya B mengalami penurunan prestasi 
belajar dan penyesuian diri terhadap teman sebayanya,serta malas mengerjakan tugas-tugas dari sekolah (PR) sehingga tidak naik kelas, selain perilaku malas belajar anak laki-laki tersebut juga suka menggangu teman-temannya (usil), suka memalak uang teman-temannya, melawan orangtua juga guru kelasnya, suka bertengkar dengan teman-temannya, melakukan pencurian seperti mencuri uang ibu, dan orang lain, serta suka berkata kotor (kasar) terhadap ibu tirinya. Kekerasan yang terjadi ini dapat mengakibatkan anak menjadi trauma dan mengalami perubahan perilaku yang tidak menyenangkan bagi orang lain dan merugikan diri anak itu sendiri juga orangtuanya yang berakibat anak mengalami prestasi belajar menurun.

Perilaku kekerasan orang tua khususnya ayah (A) terhadap anak (B) dalam bentuk kekerasan fisik maupun psikhis, telah menyebabkan hubungan anak dan ayah menjadi terganggu atau disharmonis. Perlakuan kasar ayah tidak membuat anak menjadi penurut bahkan anak menunjukkan perilaku yang bersifat menentang seperti malas mengerjakan tugas-tugas sekolah (PR), sering berkata kasar, melawan orangtua, bermain hingga tidak kenal waktu dan mempunyai perasaan takut kepada bapaknya (A).

Dalam penelitian ini peneliti menggunakan "metode penelitian kualitatif adalah penelitian yang berlandaskan pada filsafat Post-Positivisme, digunakan untuk meneliti pada kondisi obyek yang alamiah, (sebagai lawannya adalah eksperimen) dimana peneliti adalah sebagai isntrumen kunci, teknik pengumpulan data digunakan secara triangulasi (gabungan), analisis data bersifat induktif/kualitatif, dan hasil peneltian kulitatif lebih menekan makna daripada generalisasi".

Keluarga (A), sebagai pelaku kekerasan yaitu ayah kandung berinitial (A) berusia 46 tahun dengan latar belakang pendidikan sekolah dasar (belum lulus) yang memberikan pola pengasuhan terhadap anak kandungnya dengan pola pengasuhan yang salah terhadap anak kandung dengan cara kekerasan yang berinitial B berusia 11 tahun kelas III sekolah dasar jenis kelamin laki-lakai maka. Jenis perilaku kekerasan (A) terhadap anak kandung (B) yaitu: kekerasan fisik seperti: pukulan, sabetan kekerasan psikhis seperti: ancaman, bentakan, dampak kekerasan dari orangtuanya yaitu anak mengalami permasalahan dalam penyesuaian sosial yaitu: sering melawan orangtua, berkata kasar, malas mengerjakan tugas-tugas dari sekolah (PR), serta takut kepada bapaknya. Untuk mengetahui karakteristik lebih lanjut dari informan dapat diketahui melalui ungkapan pemikiran, perasaan dan tindakan yang mereka ungkapkan. Menurut hasil asessemen bahwa (A) pada saat masih kecil dan tinggal bersama kedua orangtuanya juga mengalami pengasuhan dengan cara kekerasan juga, seperti sering mendapat pukulan, bentakan juga ancaman dari ayah kandungnya. Namun demikian pengasuhan seringkali diartikan oleh orangtua terutama yang tidak memilki kapasitas parenting. Hal ini ditunjukkan diantaranya melalui perilaku kekerasan oleh orangtua. Secara umum kekerasan didefinisikan sebagai suatu tindakan yang dilakukan satu individu terhadap individu lain yang mengakibatkan gangguan fisik, mental dan spiritual. Menurut Undang-Undang Nomor 23 tahun 2002 tentang Perlindungan Anak Pasal 20 menegaskan bahwa negara, pemerintah, masyarakat, orangtua, dan keluarga bertanggung jawab untuk menjaga dan memelihara hak-hak anak.

Banyak orangtua menganggap kekerasan pada anak adalah hal yang wajar. Mereka beranggapan kekerasan adalah bagian dari mendisiplinkan anak. Menurut Wikipedia Indonesia (2006) memberikan pengertian bahwa kekerasan merujuk pada tindakan agresi dan pelanggaran (penyiksaan, pemerkosaan, pemukulan, dan lain-lain), yang menyebabkan atau dimaksudkan untuk menyebabkan penderitaan atau menyakiti orang lain. Istilah kekerasan juga berkonotasi kecenderungan untuk melakukan perilaku yang merusak. Kekerasan pada anak adalah tindakan yang dilakukan seseorang/individu pada mereka yang belum genap usia 18 tahun yang menyebabkan kondisi fisik dan atau mentalnya terganggu.

Kekerasan terjadi ketika seseorang menggunakan kekuatan, kekuasaan, dan posisinya untuk menyakiti orang lain dengan sengaja, bukan karena kebetulan meurut (Andez, 2006). Kekerasan juga meliputi ancaman, dan tindakan yang bisa mengakibatkan luka dan kerugian. Luka yang diakibatkan bisa berupa luka fisik, perasaan, pikiran, yang merugikan kesehatan dan mental. Menurut Andez (2006) kekerasan pada anak adalah segala bentuk tindakan yang 
melukai dan merugikan fisik, mental, dan seksual termasuk hinaan meliputi: penelantaran dan perlakuan buruk, eksploitasi termasuk eksploitasi seksual, serta trafficking/jual-beli anak. Sedangkan yang dimaksudkan kekerasan dalam tulisan ini adalah semua bentuk kekerasan terhadap anak yang dilakukan oleh mereka yang seharusnya bertanggung jawab atas anak tersebut atau mereka yang memiliki kuasa atas anak tersebut, yang seharusnya dapat dipercaya, misalnya orangtua, keluarga dekat, dan guru.

Menurut Sutanto (2006), kekerasan anak adalah perlakuan orang dewasa atau anak yang lebih tua dengan menggunakan kekuasaan atau otoritasnya terhadap anak yang tak berdaya yang seharusnya menjadi tanggung jawab pengasuhnya, yang berakibat penderitaan, kesengsaraan, cacat atau kematian. Kekerasan anak lebih bersifat sebagai bentuk penganiayaan fisik dengan terdapatnya tanda atau luka pada tubuh sang anak.

Jika kekerasan terhadap anak didalam rumah tangga dilakukan oleh orangtua, maka hal tersebut dapat disebut kekerasan dalam rumah tangga. Tindak kekerasan rumah tangga yang termasuk di dalam tindakan kekerasan rumah tangga (www.ocn.ne.jp) memberikan penderitaan baik secara fisik maupun mental di luar batas-batas tertentu terhadap orang lain yang berada di dalam satu rumah; seperti terhadap pasangan hidup, anak, atau orangtua dan tindak kekerasan tersebut dilakukan di dalam rumah.

Anak-anak dengan sejarah kekerasan (pelecehan) fisik, anak-anak yang mengalami kekerasan fisik akan menjadi anak-anak yang pada tumbuh kembangnya menjadi pribadi yang takut dan terhambat. Maka anak yang sering disiksa secara fisik menunjukan perilaku agresif dan perilaku menantang menurut (Kolko,1992). Anak disiksa secara fisik cenderung tidak memilki keterampilan sosial, mereka juga dicap oleh guru mereka dan teman sebaya sebagai pengganggu. Pada dasarnya mereka menampilkan perilaku yang telah mereka pelajari melalui pemodelan agresi, kontrol, dan didominasi.

Orangtua dengan sejarah kekerasan secara fisik (fisical ebused), umumnya cenderung tidak memiliki kehangatan dalam berkomunikasi maupun berinteraksi kepada anak, dalam menyalurkan kasih sayang ketika berinteraksi dengan anak-anak mereka menurut (Bousha \&Twentyman,1984; Kavanaugh, Youngblade, Reid, \& Homo, 1988). Misalnya, mereka kurang mendukung dan menggunakan sedikit hal yang positif atau kata-kata yang mendorong (misalnya, saat anak jatuh, mereka tidak akan menghibur, bahkan cenderung diam saja atau marah). Pada kenyataannya, mereka bahkan sering kurang menanggapi anak-anak mereka dibandingkan dengan orangtua yang tidak melakukan kekerasan menurut (Kavanaugh, dkk, 1988). Banyak orang tua yang kasar banyak mengalami kesulitan dengan control impuls dan mengelola dampak negatif (misalnya, kemarahan, kecemasan, depresi), mereka tampaknya menampilkan banyak emosinegative dan volatilitas sendiri, tetapi tidak mengerti masalah emosional pada umumnya. Orangtua yang kasar juga sering mengalami kesulitan dengan pemecahan masalah dan keterampilan kognitif lainnya, yang sangat jelas berkenaan dengan harapan mereka untuk perilaku anak mereka. Orangtua yang kasar juga sering memiliki ide yang kuat bahkan kaku tentang disiplin realities harapan untuk perkembangan anak.

Peneliti menemukan konstelasi permasalahan pada keberfungsian sosial keluarga. Salah satu kasus yang ditangani peneliti adalah kasus yang berinitial (A) yang berumur 45 tahun seorang ayah bekerja sebagai sopir angkutan kota yang melakukan kekerasan kepada anaknya berinitial B berumur 11 tahun dan masih duduk di sekolah dasar kelas III sebagai korban kekeran orangtua. Ia mendapatkan perlakuan kekerasan dari ayahnya (A),kekerasan yang dilakukan berupa kekerasan fisik maupun psikhis yang ditunjukan oleh orangtua (A) terhadap anak (B) dengan cara memukul, sedangkan kekerasan secara psikhis yang ditunjukan oleh orangtua (A) terhadap anak seperti ancaman dan bentakan atau omelan.

Sedangkan perilaku kekerasan fisik maupun verbal yang ditunjukan oleh anak (B) terhadap orangtua; perilaku malas secara akademis yaitu mengerjakan tugas-tugas sekolah (pr), sedangkan perilaku verbal yang ditunjukan oleh anak (B), berkata kasar terhadap orangtua maupun teman sebayanya, serta perasaan takut kepada orangtua yaitu ayahnya. 
Upaya yang dilakukan untuk mengatasi masalah (A) dan B tersebut adalah dengan menggunakan pendekatan terapi keluarga (family theraphy) yang berorientasi terhadap perubahan perilaku orangtua (ayah) dan anak secara bersamaan di mana orangtua menjadi agenagen perubahan bagi anak dan keluarga. Bentuk intervensi yang diberikan adalah pelatihan keterampilan sosial (sosial skill training) dan terapi Parent-Child Interaction Therapy (PCIT). Terapi PCIT merupakan tataran praktik Pekerjaan Sosial Klinis yang dikembangkan oleh Cheryl Bodiford McNeil . Toni L. Hembree-Kigin tahun 2005, PCIT, melalui dua fase ChildDirected Interaction (CDI) merupakan keterampilan orangtua dalam memberikan (1) Praise (Pujian) (2) Reflection (merefleksi) (3) Imitate (menirukan) (4) Describe (menjelaskan) (5) Enthusiasm dan Parent-Directed Interaction Therapy (PDI), Adapun fokus penerapan terapi yang diberikan kepada orangtua mengenai struktur keseluruhan dari Parent-Child Interaction Therapy (PCIT) melalui dua fase Child-Directed Interaction (CDI) dan Parent-Directed Interaction (PDI), Adapun tujuan pendekatan ini untuk meningkatkan hubungan dan interaksi orangtua dengan anak agar menjadi lebih efektif dalam pengasuhan penuh dengan kehangatan, dan menjadi agen-agen perubahan bagi anak.

Sebagaimana kita analogikan didalam membangun sebuah "rumah", bahwa jika kita ingin membangun sebuah rumah dengan menekankan pada sebuah "kesan", maka terlebih dahulu kita harus memiliki landasan atau pondasi yang kuat untuk membangunnya. Diperkirakan, untuk tahap membangun suatu "pondasi" maka dibutuhkan waktu dan kesabaran, tidak seperti yang terjadi pada fase Parent Directed Interaction (PDI), dimana kita bisa dengan cepat dan langsung menangani masalah perilaku. Rumah tidak akan berdiri tanpa pondasi yang kuat dan tegap. Maka orangtua diminta untuk dapat bersabar dalam fase Parent Directed Interacton (PDI) ini, lambat laun hasil ini akan mengalami perubahan yang dramatis dan cepat, terutama saat pdi dimulai.

Ada banyak tujuan yang mungkin bisa dicapai pada Child Directed Interaction (CDI), yang ditekankan pada setiap keluarga harus didasarkan pada identifikasi masalah selama proses evaluasi. Walaupun ditemukan bahwa Child Directed Interaction (CDI), dapat meningkatkan harga diri anak, juga dapat meningkatkan hubungan orangtua dan anak, mampu mengomentari pada saat anak sedang bermain, mampu membuat anak-anak tidak melawan atau menentang, dan meningkatkan toleransi dalam kegagalan untuk mencapai kesempurnaan. Terapi Child Directed Interaction (CDI) dapat dilakukan untuk masalah dalam perkembangan anak-anak seperti anak asuh, anak adopsi, anak dengan masalah internalisasi dan korban pelecehan.

Dengan melalui pendekatan teknik terapi PCIT, dimana kondisi orangtua dan anak yang mengalami masalah-masalah hubungan dalam berinteraksi kepada anak. (Herschell \& Mcneil, tahun 2010 edisi ke 2). Mengingat pelaksanaan penelitian merupakan tindak lanjut dari hasil praktikum dengan fokus pada penanganan permasalahan anak yang mengalami kekerasan dari ayahnya. Namun sebelumnya perlu disampaikan bahwa apa yang telah dilaksanakan pada saat praktikum adanya suatu perubahan pada diri (A) dan B. Perubahan perilaku (A) sudah menyadari bahwa pola pengasuhan yang diterapkan terhadap anaknya dengan cara kekerasan fisik maupun psikhis selama ini, menunjukan adanya suatu perubahan pada diri (A) telah berkurangnya dalam memberikan pengasuhan dengan cara kekerasan. Sedangkan perubahan yang dialami B yaitu adanya kemajuan perubahan dalam belajar, seperti B lebih berkonsentrasi dalam belajar sehingga B merasa termotivasi cukup tinggi serta mampu mengerjakan tugastugas sekolah dengan nilai raport baik sebagaimana hasil laporan praktikum.

Akan tetapi perubahan tersebut belum sepenuhnya mapan atau terinternalisasi pada (A) juga $\mathrm{B}$, perilaku negatif tersebut kadang terulang kembali, bahkan bisa menjadi semakin meningkat akibat stressor yang cukup tinggi, himpitan ekonomi, rendahnya pendidikan dan pengetahuan, tidak mempunyai kemampuan dalam pengasuhan (parenting skill). Oleh sebab itu dalam penanganan masalah yang muncul diantara orangtua dengan anak supaya kesadarannya meningkat serta menjadi model-model perilaku yang positif, sehingga hal ini akan dapat dengan mudah dipelajari oleh anak, sedangkan melatih orangtua untuk bertindak sebagai agen-agen perubahan bagi masalah-masalah perilaku dan emosioanal anak, perlu 
pembentukan struktur dan konsistensi penerapan disiplin dan selanjutnya orangtua melakukan pengasuhan terhadap anak tanpa adanya kekerasan yang menjadi poin yang sangat penting.

Secara umum tujuan yang hendak dicapai dari pelaksanaan terapi melalui pendekatan PCIT adalah untuk meningkatkan dan memperbaiki hubungan komunikasi orangtua dan anak serta menurunkan perilaku tindak kekerasan fisik, dan psikhis yang ditunjukkan orangtua (A) terhadap anak (B), serta menurunkan perilaku anak dari malas mengerjakan tugas-tugas sekolah, berkata kasar, serta takut kepada orangtua yaitu orangtua (A). Adapun secara khusus, proses terapi PCIT dapat tergambar pada masing-masing tahapan pelaksanaan terapi sebagai berikut :

\section{Fase CDI (Child-Directed Interaction)}

Pada fase CDI, peneliti melatih keterampilan orangtua (A) untuk dapat mengikuti arah interaksi langsung anak dalam bentuk keterampilan p-r-i-d-e (Praise, Reflection, Imitate, Describe, And Enthusiastic). Proses keterampilan ini akan dilakukan oleh orangtua (A) dan keluarga sebagaimana diarahkan peneliti, dengan tahapan-tahapan sebagai berikut:

a. Orangtua (A) melakukan keterampilan memberikan pujian (praise) dalam bentuk pujian berlebel spesifik maupun pujian umum terhadap anak (B), ketika anak menampilkan sikap atau perilaku yang positif terhadap orangtuanya.

b. Orangtua (A) melakukan keterampilan untuk mampu mendengarkan kata-kata yang diucapkan oleh anak, orangtua mampu merefleksikan (reflection) apa yang dikatakan anak. Artinya bukan sekedar memberikan anggukan kepala menyatakan tanda setuju, namun justeru orangtua harus bisa merespon dan mendengarkan secara baik apa yang dikatakan anak sebenarnya. Hal ini supaya apa yang dikatakan anak, betul-betul bahwa orangtua mendengarkannya, maksudnya apa yang diucapkan oleh anak itu merasa didengar orangtuanya (menghargai hak anak).

c. Orangtua (A) melakukan keterampilam untuk mampu memberikan (imitatete) apa yang diperbuat oleh orangtua (A), artinya perilaku orangtua akan ditiru oleh anak (B) dan akan menjadikan cerminnan yang baik bagi anak.

d. Orangtua (A) melakukan keterampilan untuk mampu memberikan (discribe), ketika anak sedang bermain sesuai dengan perilaku anak, orangtu diminta untuk mampu memberikan atau mengomentari apa yang sedang anak lakukan dengan berbicara netral mencakup pertanyaan anak.

e. Orangtua (A) melakukan keterampilan untuk mampu memberikan (enthusiastic) ketika anak melakukan kegiatan yang sedang dilakukan anak (B) bersama orangtua, orangtua mampu menunjukan ekspresi kegembiraanya ketika bermain bersama anak, dan orangtua mampu memberikan pujian ketika anak menampilkan perilaku yang positif yang dikehendaki orangtua.

2. Fase PDI (Parent-Directed Interaction)

Pada fase PDI, peneliti melatih keterampilan orangtua (A) untuk dapat memberikan instruksi pada anak yang bersifat positif dan saling hormat menghormati yang berisikan 9 (sembilan) prinsip instruksi yang harus dilakukan orangtua terhadap anak (B), yaitu: 1) bersifat langsung, perintah diberikan langsung dengan menyuruh anak, dan bukan bertanya, 2) bersifat positif (what to do, not stop doing), dalam memberikan perintah dalam kalimat yang jelas sesuai dengan usia anak, 3) tunggal (satu perintah dalam satu kurun waktu), 4) tegas dan jelas ketika menyampaikan instruksi, 5) mudah dipahami, yaitu menyampaikan perintah dengan kalimat yang mudah dipahami, 6) intonasi dan tekanan suara normal, perintah yang dberikan kepada anak harus menggunakan intonasi dan tekanan suara yang normal (meskipun kondisi orangtua sedang marah), 7) waktu yang tepat, jangan terlalu sering memberikan perintah dan gunakan kalimat perintah jika benar-benar dibutuhkan, 8) sopan dan penuh rasa hormat, memberikan perintah dalam bentuk permintaan dan bukan sebuah 'komando', 9) menjelaskan atau memaknai, berikan penjelasan terlebih dahulu sebelum menyuruh anak atau sesudah anak melakukan permintaan orangtua. 


\section{METODE PENELITIAN}

Metode penelitian ini menggunakan pendekatan kualitatif yang merupakan pendekatan suatu pendekatan penelitian yang didasarkan atas setting alamiah. Selanjutnya ditegaskan pula bahwa penelitian kualitatif juga merupakan penelitian lapangan sebagaimana dikemukan robert emerson yang dikutip oleh Grinnel (1997:107),yaitu:

"qualitative research is the study of people in their natural environmnets as their daily lives. It tries to understand how people live, how they talk and behave, and what captivates and distresses them....more importantly, it strives to understaand the meaning people's wor(A) and behaviors have for them."

Dalam penelitian ini rancangan yang digunakan mempertimbangkan tahapan-tahapan dalam penelitian tindakan, sebagai berikut : 1) refleksi yaitu melakukan pengkajian hasil asemen dan PCIT melalui dua fase CDI dan PDI terhadap pola pengasuhan orangtua, tahap, 2) perencanaan yaitu merencanakan pelaksanaan model PCIT melalui dua fase CDI dan PDI dan uji model meliputi diskripsi program, indikator keberhasilan, rencana kerja dan kalender kerja, 3) pelaksanaan tindakkan dilakukan berdasarkan hasil perencanaan kegiatan yang telah tersusun, 4) tahap refleksi akhir, observasi untuk melihat perilaku yang ditampilkan sehari-hari dari orang yang telah diteliti dan dijadikan sebagai sumber data penelitian.

Untuk itu rancangan tahapan penelitian tindakkan dapat digambarkan sebagaimana bagan berikut dibawah ini :

\section{Bagan 1. Tahapan-tahapan Parent-Child Interaction Therapy (PCIT). Operasionalisasi dalam penelitian tindakan}

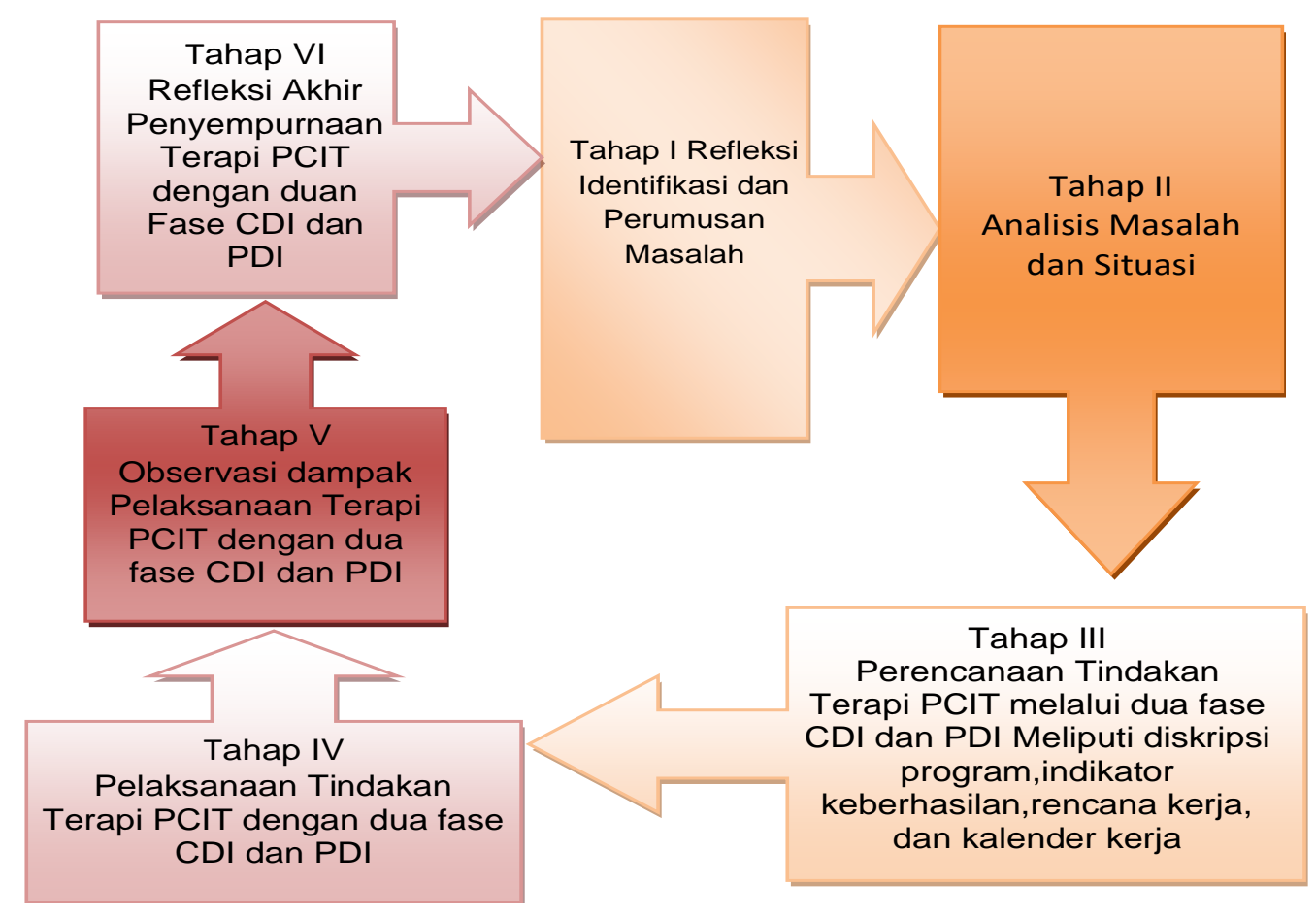

\section{Gambar 1. terapi parent child interaction teraphy (PCIT) untuk mengurangi perilaku kekerasan orangtua terhadap anak}

\section{HASIL DAN PEMBAHASAN}

Hasil penelitian yang dilaksanakan merupakan suatu kegiatan profesional dengan tujuan untuk mendapatkan suatu model pemecahan masalah pola pengasuhan dalam keluarga yang memperlakukan anaknya dengan cara kekerasan fisik maupun psikhis. Fokus utama dalam penelitian ini adalah memberikan bantuan pada keluarga yang mengalami permasalahan dalam pola pengasuhan dengan cara kekerasan. Sebagai tindakan profesional maka penerapan 
berbagai pengetahuan, nilai dan keterampilan pekerjaan sosial merupakan unsur pertama dan menjadi penting dalam melakukan penelitian. Menurut McNeil, Cheryl Bodiford., Toni L. Hembree-Kigin. (2010). Parent-Child Interaction Therapy. Second Edition. USA: Springer. Terapi Parent Child Interaction Theraphy (PCIT) merupakan salah satu terapi keluarga berdasarkan model pendekatan pengubahan perilaku. PCIT mengharuskan orangtua dengan anak secara bersamaan di mana orangtua menjadi agen-agen perubahan bagi anak. Dengan demikian kegiatan dalam penelitian ini diharapkan berimplikasi secara praktis dan teoritis dalam memperkaya pengembangan ilmu pekerjaan sosial di Indonesia, khususnya yang berkaitan dengan penyelenggaraan proses pelayanan dalam pekerjaan sosial.

\section{Implikasi Praktis}

Implikasi praktis merupakan sesuatu hal yang diperoleh berdasarkan pelaksanaan penelitian terhadap keluarga yang telah berhasil merubah pola pengasuhan orangtua terhadap anak dengan tidak lagi melakukan tindakan kekerasan. Penerapan model yang telah dilakukan oleh peneliti pada dua fase yaitu pada fase CDI dan fase PDI, membawa beberapa implikasi praktis yang dapat dijelaskan sebagai berikut:

1) Implikasi model saat penelitian model intervensi PCIT dengan dua fase ChildDirected Interaction (CDI) dan dan Parent Directed-Interaction (PDI)

Implikasi model pendekatan fase CDI dan PDI melalui PCIT ini adalah menyesuaikan antara tujuan pola pengasuhan orangtua diaplikasikan dengan tahapan-tahapan yang ada dalam fase CDI dan PDI. Berdasarkan temuan atau hasil dari penyempurnaan model akhir rencana intervensi dalam penelitian sebagaimana terdapat dalam bagan di atas, maka model ini dapat diimplementasikan dalam kegiatan penerapan CDI dan PDI dalam PCIT sebagaimana hasil di bawah ini:

\section{2) Implikasi model intervensi dengan fase CDI, yaitu melalui P-R-I-D-E:}

\section{a) Praise}

Keterampilan A dan keluarganya dalam memberikan pujian berlabel (spesifik) maupun tidak berlabel (umum) terhadap B, untuk menyampaikan persetujuan kasih sayang dengan tanpa menentukan apa yang orangtua suka atau dihendaki. Di mana ketika anak (B) menampilkan perilaku negatif maka orangtua tidak terpancing emosi dan mengabaikan serta tidak memberikan hukuman kekerasan secara fisik dan psikhis terhadap B

\section{b) Reflection}

Keterampilan A dan keluarganya agar mampu merefleksikan serta mampu mendengarkan ketika anak sedang berbicara kepada orangtua. Orangtua mampu merefleksikan apa yang anak (B) katakan, sehingga apa yang diucapkan anak (B) merasa didengar dan dihargai oleh orangtuanya, dan ketika anak (B) menampilkan perilaku negatif maka orangtua tidak terpancing emosi serta mengabaikan dan tidak memberikan hukuman kekerasan secara fisik dan psikhis terhadap B.

\section{c) Imitate}

Keterampilan A dan keluarganya mampu memberikan imitasi atau mengikuti apa yang sedang dilakukan anak (B), ketika anak (B) menampilkan perilaku negatif maka orangtua tidak terpancing emosi serta mengabaikan dan tidak memberikan hukuman kekerasan secara fisik dan psikhis terhadap B.

\section{d) Describe}

Keterampilan orangtua (A) dan keluarganya dalam memberikan penjelasan terhadap anak (B), dengan nada datar dan netral dan ketika anak (B) menampilkan perilaku negatif yang tidak dikehendaki orangtua maka A mengabaikan dan tidak terpancing emosi serta tidak memberikan kekerasan secara fisik dan psikhis terhadap B

\section{e) Ethusiastic}

Keterampilan orangtua (A) dan keluarganya dalam menunjukan ketertarikan dan rasa senang, ketika B menampilkan perilaku positif yang ditunjukan B terhadap orangtua. Orangtua mampu memberikan anthusias terhadap anak dengan cara memberikan pujian serta 
penghargaan terhadap B, baik dengan gestuur maupun hadiah langsung. Sehingga anak merasa dihargai serta merasa ada suatu kehangatan didalam keluarga, dan ketika B menampilkan perilaku negatif maka orangtua tetap mengabaikan dan tidak terpancing emosi, serta tidak memberikan hukuman kekerasan

3) Implikasi model intervensi dengan fase Parent Directed Interaction (PDI), yaitu melalui Sembilan prinsip instruksi yang harus dilakukan orangtua terhadap anak:

\section{a) Bersifat lansung dan bukan bertanya,}

Pada tahapan ini kemampuan A dalam memberikan perintah terhadap B bersifat langsung dan bukan bertanya yang menjadi fokus utama bagaimana implikasi membentuk A melakukan perintah terhadap B dengan nada langsung dangan nada lirih dan lembut hanya satu keinginan. Peneliti menggunakan tehnik educator, fasilitator dan evaluator mempersiapkan orangtua, anak dan keluarga dengan seperangkat pengetahuan dan keterampilan yang diperlukan untuk memahami proses pelaksanaan aplikasi CDI tersebut. A menggunakan kalimat dan cara yang santun ketika menyuruh B dengan ketelatenan serta kesabaran, keingnginan A beserta keluarga yang kuat untuk merubah pola pengasuhan yang baik terhadap $B$, disinilah seni peneliti menjebatani antara A beserta keluarganya perubahan pola pengasuhan terhadap B untuk saling menghargai dan menghormati serta mampu memberikan pujian terhadap A sesuai dengan hakhak anak (gesture). Sehingga B merasakan keinginan atau perintah A satu keinginan yang jelas yang harus dilaksanakan bahwasannya ayah A membutuhkan bantuan dari B. Untuk memantau perubahan A dan keluarganya peneliti menggunakan teknik observasi terhadap seluruh anggota keluarganya pada waktu yang berbeda dengan teknik wawancara. B pun tidak mempunyai keinginan menolak karena dirinya merasakan dibutuhkan dan dihargai oleh keluarganya dan B merasa adanya suatu kehangatan. Ketika B tidak mematuhinya maka A tidak perpancing emosi dan mengabaikan serta tidak memberikan hukuman fisik maupun psikhis.

\section{b) Bersifat positif (what to do, not stop doing)}

Pada tahapan ini peneliti menggunakan tehnik fasilitator dengan memfasilitasi link's age antar orangtua A, keluarga serta anak (B), peneliti menjebatani bagaimana memberikan pola pengasuhan terhadap anak untuk memberikan perintah terhadap B bersifat positif dan jelas, peneliti juga mengngunakan teknik pekerja sosial dengan model untuk tidak dengan nada yang keras serta melakukan kekerasan secara fisik dan psikhis terhadap anak. Keingnginan A dan keluarga yang kuat untuk merubah pola pengasuhan terhadap B, A dan keluarga ketika menyuruh B dengan menggunakan nada datar dan santun juga mampu memberikan alternatifalternatif dari segi positif dan negatif untung dan rugi bagi B. A mempunyai kemampuan dalam memberikan perintah positif terhadap B dan mampu memberikan larangan yang merugikan bagi B. Dan ketika B tidak mematuhinya maka A dan keluarga tidak memberikan hukuman fisik maupun psikhis.

\section{c) Tunggal satu perintah}

Pada tahapan ini kemampuan A dalam memberikan perintah terhadap B dengan perintah satu persatu sehingga B mampu mengerjakan dengan baik. Pada tahapan ini menegaskan kembali peran orangtua terhadap pola pengasuhan terhadap anak sehingga anak mampu mematuhi apa yang dikehendaki orangtua yang sangat penting, dalam memberikan perintah terhadap B dengan perintah satu-persatu mengingat usia B masih usia anak yang masih dalam tahap belajar untuk mematuhi atau patuh terhadap orangtua maka dalam hal ini A dan keluarga pun memahami dan tidak melakukan atau memberi perintah yang sifatnya bertumpuk terhadap B. Dan ketika B tidak mematuhi ketika orangtua memberi perintah terhadap B maka A dan keluarganya tidak memberikan hukuman secara fisik dan psikhis terhadap B.

\section{d) Perintah dengan jelas dan tegas}

Pada tahapan ini kemampuan A dalam memberikan perintah dengan jelas dan tegas terhadap B sehingga B mampu dan mengerti apa yang orangtua perintahkan, dan B mampu mengerjakan dengan baik. Pada tahapan ini peneliti melakukan sheer terhadap A dan keluarganya bagaimana memberikan perintah terhadap perilaku B dengan jelas sehingga $\mathrm{B}$ mampu memahami apa yang orangtua kehendaki. Dan ketika B tidak mematuhi maka A tidak 
memberikan hukuman secara fisik dan psikhis terhadap B dan ketika B mematuhinya maka A dan keluarganya memberikan hadiah terhadap B.

e) Memberikan perintah mudah dipahami

Pada tahapan ini kemampuan A memberikan perintah terhadap B dengan kalimat nada datar dan netral, pada tahapan sesi ini menegaskan Kembali peran orangtua terhadap pola pengasuhan yang sangat menjadi penting dalam memberikan perintah terhadap B tidak harus dengan bentakan teriakan, dan perlunya memberikan perubahan pola pengasuhan dengan kalimat datar dan netral, sehingga B mampu merespon dari orangtua dengan nada ucapan yang netrall, dengan nada netral menyiratkan ketegasan sebuah pendekatan. Karakteristik A, dengan latar belakang pendidikan dan lingkungan tempat tinggal serta faktor eknomi yang mempengaruhi belum bisa merubah A untuk mampu berucap nada pelan bila memberika perintah terhadap $\mathrm{B}$, sehingga masih menunjukan kesan bahwa A belum mengalami ada perubahan. Peneliti menggunakan teknik pekerja sosial seperti memberikan support dan keyakinan bahwa A dan keluarganya tidak akan dilakukan kembali apa bila menyuruh anak dengan nada keras atau dengan bentakan. Peneliti menyadari bahwa A sedang menjalankan proses perubahan dalam pola pengasuhan terhadap anak.

\section{f) Perintah dengan intonasi dan tekanan suara normal}

Pada tahapan ini kemampuan A dalam memberikan perintah dengan nada tekanan suara yang datar dan tekanan suara yang normal masih menunjukkan nada atau intonasi tinggi, hal ini dikarenakan karakteristik A yang berintonasi keras dan terkesan kasar ini masih belum ada perubahan sehingga B masih mempunyai perasaan takut ketika A memberikan perintah terhadap B. Pada tahap sesi ini peneliti bersama A dan G sebagai kontrol perubahan terhadap A, titik tekan dalam pertemuan ini pada kemampuan A serta pendapat A tentang memberikan perintah dengan intonasi dengan nada datar dengan tekanan suara normal di mana keluarga $\mathrm{A}$ sepakat untuk merubah pola pengasuhan tanpa dengan teriakan dan bentakan, A dan keluarga menyadari B sudah mulai remaja dan tidak perlu lagi memberikan perintah dengan ucapan yang tinggi. Serta sepakat tidak lagi memberikan hukuman dengan kekerasan secara fisik psikhis terhadap B. Peneliti menggunakan teknik observasi tentang perubahan pola pengasuhan A terhadap B, diluar sesi tersebut dan wawancara langsung kepada B berkaitan dengan kemampuan A memberikan perintah terhadap B bahwa A tidak meberikan bentakan serta teriakan ketikan menyuruh anak A mampu memberikan anggukan dan senyuman ketika B melakukan perintah dari orangtuanya dan ketika B menolak atau tidak melakaukan perintah dari orangtuanya, A pun tidak terpancing emosi dan tidak memberikan hukuman terhadap B baik fisik maupun psikhis.

\section{g) Memberikan perintah pada saat yang tepat serta tidak sering memberikan perintah}

Pada tahapan ini peran orangtua dalam kemampuan memberikan perintah terhadap B dalam situasi-situasi tertentu yang dirasakan akan merugikan diri B, pada tahapan sesi ini peneliti memberikan pemahaman terhadap A dan keluarganya untuk sepakat dan konsisten dalam memberikan perintah pada saat-saat tertentu yang berpotensi akan menguntungkan dan merugikan diri B, sehingga masing-masing menunjukan perilaku yang kopetensi bahwa bahwa masing-masing saling menghargai dan menghormati aturan keluarga yang telah ada, perubahan perilaku keseharian menjadi penting dalam kehidupan berkeluarga. Dan ketika B tidak konsisten atau melanggar aturan keluarga A dan keluarganya tidak memberikan hukuman kekerasan fisik maupun psikhis terhadap B, orangtua untuk mengabaikan dan tidak terpancing emosi.

\section{h) Memberikan perintah dengan sopan dan penuh rasa hormat}

Pada sesi ini kemampuan A dalam memberikan perintah dengan nada sopan dan menghormati hak-hak anak, hal ini berkaitan dengan pola pengasuhan yang baik terhadap anak dan keinginan A yang kuat untuk dapat merubah perilaku anak, sehingga keingnginan yang kuat A untuk dapat menjadi modeling bagi anak, A dan keluarga sepakat untuk merubah kebiasaan yang tidak baik dalam memberikan perintah terhadap B yang selalu memberikan 
perintah tanpa menghormarti terhadap anak maupun anggota keluarganya, dalam hal ini peneliti memberikan evaluasi terhadap keluarga A bahwa saling menghargai dan menghormati terhadap oranglain itu sangat berarti apalagi terhadap keluarga sendiri, peneliti sebagi educator mencoba terhadap keluarga A untuk dapat memulainya dan membiasakan diri setiap akan memberikan perintah terhadap anak agar selalu diawali dengan kata "tolong" (please-eng), dalam kebiasaan ini anak akan merasa dihargai dan perilaku orangtua akan ditiru juga menjadi permanen terhadap anak akan meniru pula dengan kata tolong, anak akan merasa dihargai sebagai mana hak-hakanya. Dan ketika B tidak memathu perintah orangtua maka orangtua tidak memberikan hukuman kekerasan fisik maupun psikhis terhadap anak (B), dan ketika B mematuhinya maka orangtua memberikan pujian sesuai dengan hak-haka anak gesture terhadap anak.

\section{i) Perintah dengan memberikan penjelasan serta memaknai terlebih dahulu sebelum menyuruh}

Dalam tahapan ini kemampuan A sebelum memberikan perintah terhadap B. Pada tahap sesi ini peneliti menggunakan teknik pendekatan terhadap A dan keluarganya sebagai peran orangtua terhadap pola pengasuhan yang tepat menjadi fokus yang harus dilakukan orangtua dalam memberikan perintah terhadap B yang harus didengarkan oleh B, terlebih dahulu A dan keluarganya mampu menjelaskan apa yang akan diinginkan orangtua step by step dari unit yang besar ke unit yang terkecil sehingga B mudah memahaminya. Dan ketika B mematuhi perintah orangtua mampu memberikan pujian baik berbentuk gesture terhadap B, dan ketika B tidak mematuhihya maka orangtua tidak terpancing emosi serta tidak memberikan hukuman secara fisik maupun phisikis terhadap B.

\section{KESIMPULAN}

Kesimpulan hasil penelitian menunjukan bahwa terapi PCIT melalui dua fase Child Directed-Intarction (CDI) dan Parent Directed-Interaction (PDI), efektif dapat memperbaiki hubungan orangtua dan anak menjadi penuh kehangatan serta orangtua mampu memberikan pola pengasuhan terhadap anak tanpa melakukan kekerasan baik secara fisik maupun psikhis. Implementasi teoritis bahwa terapi PCIT ini memberikan konstribusi menguatkan teori gaya pengasuhan autoritatif (autoritative parenting style) pengasuhan yang penuh dengan kehangatan dan menambah bukti empiris terhadap asumsi yang ada pada teori tersebut.

\section{DAFTAR PUSTAKA}

Brestan, EV, Eyberg, SM, Boggs, SR, \& Algina, J. (1997) The PCIT website (www.pcit.org) Gunarsa, S.D. (1990). Dasar dan Teori Perkembangan Anak. Jakarta: BPK Gunung Mulia. Herschell, A.D., Calzada, E.J., Eyberg, S.M., \& McNeil, C.B. (2002). Parent-Child Interaction Therapy: New Directiond in Research. Cognitive and Behavioral Practice

Hurlock, Elizabet B. (1980). Development Psychology. A Life-Span Apprach, Fifth Edition. Boston: McGraw-Hill, Inc.

McNeil, Cheryl Bodiford., Toni L. Hembree-Kigin. (2010). Parent-Child Interaction Therapy. Second Edition. USA: Springer.

Undang - Undang Nomor 23 Tahun 2002 tentang Perlindungan Anak

Undang - Undang Nomor 3 Tahun 1997 tentang Pengadilan Anak. 